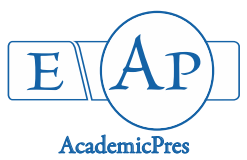

Dey K et al. (2021)

Notulae Scientia Biologicae

Volume 13, Issue 2, Article number 10963

DOI: $10.15835 /$ nsb13210963

Research Article

\title{
Avifaunal diversity and ecotourism opportunities: A case study from Barachaka tribal village of Bankura, West Bengal, India
}

\author{
Kamala DEY ${ }^{1}$, Tapas K. DUTTA ${ }^{2}$, Rajendra P. MONDAL ${ }^{2 *}$ \\ ${ }^{1}$ Midnapore College (Autonomous), Department of Microbiology, Midnapore,721101, West Bengal, India; \\ kamala.dey@midnaporecollege.ac.in \\ ${ }^{2}$ Bankura Sammilani College Department of Zoology, Bankura,722102, West Bengal, India; tdutta98@gmail.com; \\ rpmondal09@gmail.com (*corresponding author)
}

\begin{abstract}
Ethnic people throughout the globe are engaged in the conservation of biodiversity. The objective of this study was to measure the avifaunal diversity in heterogeneous forest and paddy fields surrounding the Barachaka tribal village of West Bengal, India and the prospect of development of ecotourism spot in this area. The study was conducted during June and July of 2019 and 2020. A total of 47 bird species belonging to 27 families were identified and recorded during the span of study. Among these bird species, Asian open bill stork (Anastomus oscitans) is predominant in the heterogeneous forest of this village and they usually used this place as a breeding ground during the rainy season. The study reveals that the safety and food security provided by the villagers encourage these birds to prepare colonial nests in trees very near to the human habitation. Shannon-Wiener diversity index value was recorded 2.49 within village forest and 2.33 in the paddy field during June 2019 and July 2019 and 2.62 within village forest and 2.47 in the paddy field during June 2020 and July 2020. Results obtained from the questionnaire survey revealed that tribal people of this village are directly attached to bird conservation in their area and these tribal people protect the bird generation after generation through their traditional knowledge. The community-based bird monitoring programs may protect birds as well as wildlife and encourage researchers who may gather scientific knowledge from these ethnic people. The village under study has the prospective to develop into a good bird watching site, where bird lovers may watch the birds in nature and thereby helping the socio-economic development of the tribal people of this village.
\end{abstract}

Keywords: biodiversity; bird; conservation; ethnic; indigenous; tribal

\section{Introduction}

Birds can act as good bio-indicators and useful models for detecting environmental degradation (Kattan and Franco, 2004). So, documenting and explaining spatial patterns in species diversity is important in protecting global biodiversity (Lee et al., 2004). Species evenness and richness are two main criteria to measure species biodiversity in any area (Harisha and Hosetti, 2009). The avifaunal diversity of any region depends on vegetation pattern, food availability, climatic condition and many other factors. Approximately 1300 avifaunal

Received: 03 May 2021. Received in revised form: 26 May 2021. Accepted: 02 Jun 2021. Published online: O7 Jun 2021.

From Volume 13, Issue 1, 2021, Notulae Scientia Biologicae journal uses article numbers in place of the traditional method of continuous pagination through the volume. The journal will continue to appear quarterly, as before, with four annual numbers. 
diversity is observed in the Indian subcontinent because of its varied climatic condition, diverse landscape with unique vegetation attracts and provide habitat for many bird species around the year (Grimmett et al., 1999).

The concept of important bird areas (IBA) was developed to shield sites where naturally occurring bird population were abundant as well as conserve biodiversity in general. The concept emphasises the practical index of site-wise diversity and condition of the ecosystem. Therefore, it is important to protect such sensitive, delicate and ecologically rich habitats in the world to protect wildlife biodiversity (Birdlife, 1996). From time immemorial the ethnic people throughout the globe are actively engaged in the conservation of both faunal and floral diversity through the application of generational traditional knowledge. This is necessary for the survival of many plants and wildlife which have nutritional and aesthetic value. This knowledge has been successfully transferred from generation to generation. These people and their traditional knowledge must be integrated into contemporary ecological and anthropological research to assure the development of a successful biodiversity conservation strategy. Every social group gains their traditional knowledge for which they are the sole proprietors and which forms an important aspect of their cultural identity. The traditional knowledge, beliefs and behaviour of local communities are critical in both sustaining them and in attaining the goal of sustainable natural resource management (Rist et al., 2003). Local communities believe that the scared grooves and the deities placed within them protect their community and the villages from different natural calamities (Khan et al., 2008). The sacred groves have immense significance in habitat conservation through the participation of ethnic communities (Gadgil and Vartik, 1976). In many regions, ethnic communities play an important role in protecting heronries from poachers, predators and other enemies. Indigenous people have developed vast conservation knowledge critical to their survival, handed down through generations. Based on such knowledge, they have established guidelines for biodiversity conservation through a process of trial and error over a span.

In India dominant trend of avifaunal diversity was conducted on endangered birds, wetland birds, and birds found in various national parks, sanctuaries and other IBA (Important Bird Area) (Urfi, 2005). Few region-specific documentations of heronries birds (Nayak, 2021), vulnerable species (Mondal et al., 2014), wetland birds (Mondal and Dutta, 2019) and avifaunal diversity of some remote areas like university campuses, institutes (Praveen and Joseph, 2006) and atomic power station (Hussain et al., 2011).

In many countries, bird watching a rapidly growing ecotourism activity. Birds of any region have immense importance for their pest control, pollination and seed dispersal nature as well as their cultural and potential tourism value. Avitourism is now an emerging field of tourism that mainly emphasises nature-based tourism focusing on bird watching (Steven et al., 2014). The main attractions of avitourism are observing various kinds of attractive coloured birds and study the behaviours of birds in their natural habitat (Sitanggang et al., 2020). It encourages the researcher to collect data from nature as well as access habitat condition of that particular area. Although accumulation of more people in bird watching site has both positive and negative impact (Jones, 2010; Sodhi, 2011). The main objectives of the present study were to identify the distribution and diversity of bird in the village and paddy fields surrounding the tribal village as well as to measure the species diversity and species richness of that area. The purpose of this study was also to access the potential for the development of a popular bird-watching site or avitourism-based tourism in the study area by exploring out the ethnic people's knowledge of that area.

\section{Materials and Methods}

\section{Studyarea}

This study was conducted in the 'Barachaka Pakhiralaya' near the Barachaka tribal village $\left(23^{\circ} 19^{\prime} 13^{\prime}\right.$ ' $\mathrm{N}$ and $87^{\circ} 00^{\prime} 20^{\prime \prime} \mathrm{E}$ ), of Bankura District in West Bengal, India during the month of June and July, 2019 and 2020 (Figure 1). Three water bodies are in close proximity to this study area. Total area of the village is about 
44.22 hectares. This working area is mainly dry and arid with agricultural lands around the village. This village is also surrounded by various types of big trees where open bill stork and other birds reside.

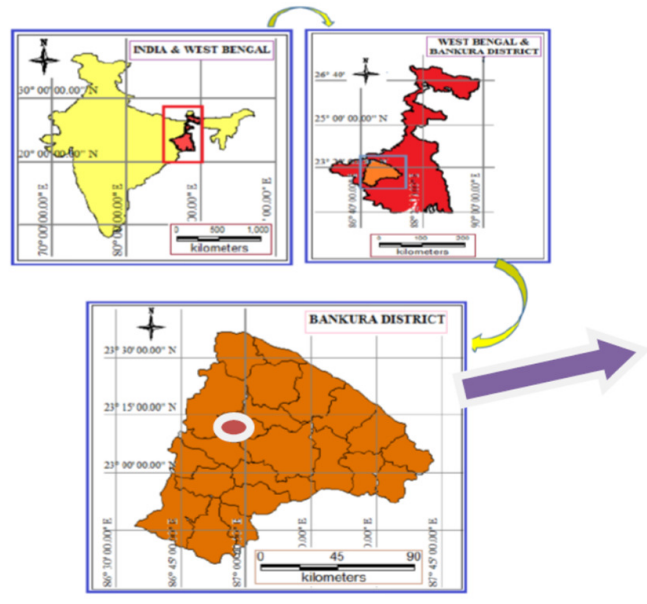

(a)

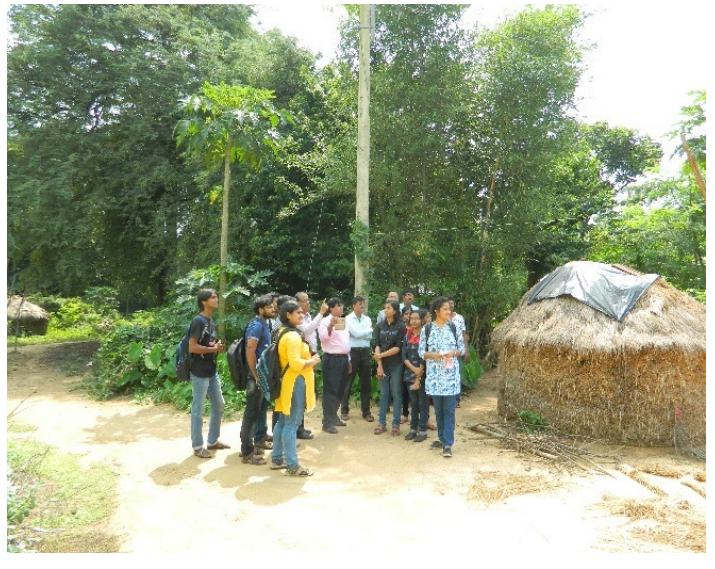

(b)

Figure 1. Geographical location of the study area

(a) India, West Bengal and Bankura District map was prepared using QGIS software and (b) Study site image

\section{Bird survey}

During this study, line transects survey and point surveys were done in this working area in the month of June and July, 2019 and 2020.The time selected for this survey was $6.30 \mathrm{am}$ to $7.30 \mathrm{am}$ once in a week. The bird count was done by walking surrounding paddy fields and heterogeneous forest inside the village with the help of a binocular (Olympus) and photographed by a digital camera (Nikon-D7200) from time to time. The line transect survey one $200 \mathrm{~m}$ straight line was laid and during walking on the straight line and bird or bird call were recorded on either side of the transect. The visibility on either side varied from $15 \mathrm{~m}$ to $50 \mathrm{~m}$ depending upon the structure of plants but in the paddy field visibility on either side varied from $20 \mathrm{~m}$ to $100 \mathrm{~m}$. A $150 \mathrm{~m}$ gap was given between two transects to overcome the repetition of bird count. For the point survey method 10 points were selected in each habitat and birds were counted $50 \mathrm{~m}$ surrounding the point. All the birds were minutely counted during this study period.

\section{Species diversity and species richness}

The study was conducted by rigorous field visits and questionnaire surveys. Species pinpointing was undertaken of mixed colonies of breeding heronry using the field guide (Kharkongor and Tiwari, 2017). The breeding population of various species, especially the Asian open bill stork, was determined by counting the nests and the presence of adult birds (Narayanan and Vijayan, 2007). In addition, data has been collected from secondary sources through conversations with ethnic people (Figure 1), official documents of respective government departments, and data from books and journals.

Species richness and species diversity was measured by Shannon-Weiner (Shannon and Weaver, 1949) to evaluate the bird species diversity in the study area. Shannon diversity index was commonly used for comparing diversity between various habitats. To know the species diversity in different habitat (Clarke and Warwick, 2001; Hutchison, 1970) Shannon diversity index was calculated by using the following formula:

$$
\mathrm{H}^{\prime}=-\left[\sum \mathrm{Pi} \ln \mathrm{Pi}\right]
$$

Where, $\mathrm{H}^{\prime}=$ Diversity Index; $\mathrm{Pi}=$ is the proportion of each species in the sample; $\ln \mathrm{Pi}=$ natural logarithm of this proportion. 
Evenness index $\left(\mathrm{J}^{\prime}\right)$ of bird species in two different habitats were calculated by using the following formula:

$\mathrm{J}^{\prime}=\mathrm{H}^{\prime} / \mathrm{H}_{\max }$

Where $\mathrm{H}^{\prime}$ is the Shannon Wiener Diversity index and $\mathrm{H}_{\max }$ is the natural $\log$ of the total number of species.

\section{Results}

\section{Bird diversity}

Since a large area of this village is covered by nesting trees and other herbs, many resident bird species indigenous to this area are seen. A total of 1,176 birds representing 47 species and 27 families were identified from the heterogenous forest of the tribal village in the month of June and July, 2020 (Table 2). Ardeidae was the dominant family in the study area with 6 species, followed by Columbidae with 5 species (Table 2) in the village forest. In the paddy field 914 birds representing 38 species were observed during June and July, 2020 but in 2019 it was 791 (Figure 2). In the forest area, the Shannon-Weiner diversity index value of avifauna calculated to be 2.49 in the June-July, 2019 and 2.62 in the June-July, 2020.Similarly in paddy field ShannonWeiner diversity index was 2.33 in June-July, 2019 and in the month of June-July, 2020it was 2.47. Species evenness was more or less same in both the habitat during the study area (Table 1 ).

Table 1. Avifaunal diversity of Barachaka tribal village

\begin{tabular}{|l|c|c|c|}
\hline \multirow{2}{*}{ Diversity index } & Year & \multicolumn{2}{|c|}{ Result } \\
\cline { 2 - 4 } & $\begin{array}{c}\text { Heterogeneous forest inside } \\
\text { the village }\end{array}$ & $\begin{array}{c}\text { Paddy fields surrounding } \\
\text { village }\end{array}$ \\
\hline \multirow{2}{*}{ Overall abundance } & June -July, 2019 & 1011 & 791 \\
\cline { 2 - 4 } & June -July, 2020 & 1176 & 914 \\
\hline \multirow{2}{*}{ Shannon Wiener index } & June -July, 2019 & 2.49 & 2.33 \\
\cline { 2 - 4 } & June -July, 2020 & 2.62 & 2.47 \\
\hline \multirow{2}{*}{ Species evenness } & June -July, 2019 & 0.67 & 0.67 \\
\cline { 2 - 4 } & June -July, 2020 & 0.68 & 0.68 \\
\hline \multirow{2}{*}{ Species richness } & June -July, 2019 & 41 & 33 \\
\cline { 2 - 4 } & June -July, 2020 & 47 & 38 \\
\hline
\end{tabular}

In village, many heronry birds prepare a nest in trees during late summer and rainy season and lay eggs. These birds were categorized as early arrivers, late arrivers, and very late arrivers (Figure 5). Early arriving birds include the Black-crowned Night Heron (Nycticorax nycticorax), Cattle Egret (Bubulcus ibis). Late arriving birds include the Indian Pond Heron (Ardeola grayii), Asian open bill stork (Anastomus oscitans) and Very late arriving birds include the Eurasian Spoonbill, Little Cormorant (Microcarbo niger). Other frequently observed resident birds are Sparrow (Passer domesticus), Purple Sunbird (Cinnyris asiaticus), Kingfishers (Alcedo atthis), Asian Koel (Eudynamys scolopaceus), Lesser Golden-backed Woodpecker (Dinopium benghalense), Black-headed Oriole (Oriolus xanthornus), Common Myna (Acridotheres tristis), Red Vented Bulbul (Pycnonotus cafer), Oriental Magpied-Robin(Copsychus saularis). Among all Asian open bill stork (Anastomus oscitans) are predominant among birds (Table 2). The villagers knowingly or unknowingly protect these birds along with Asian open bill stork. 


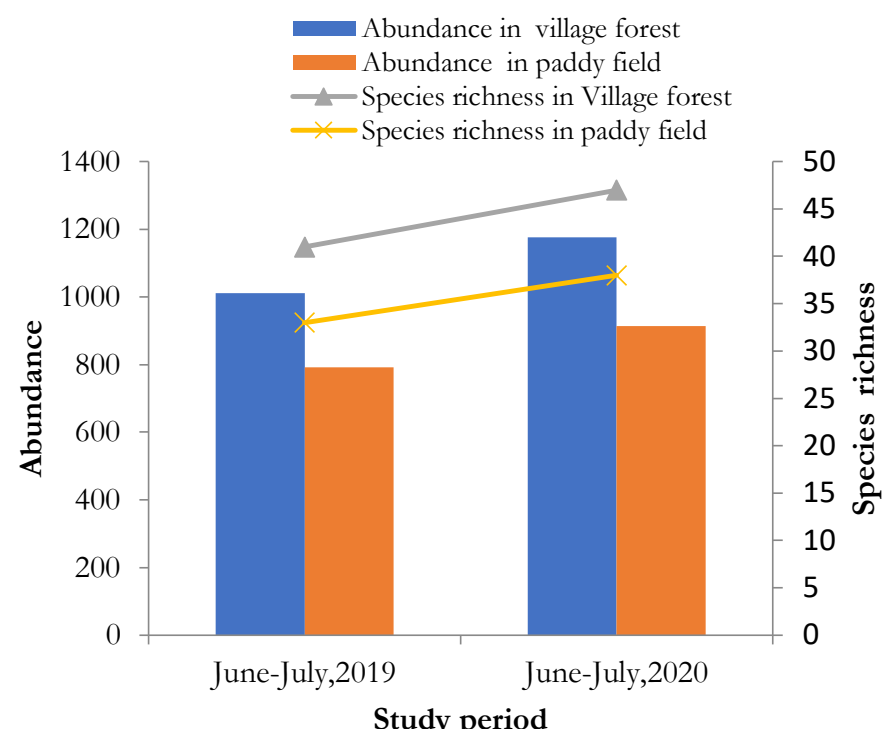

Figure 2. Comparison of bird abundance and species-richness in heterogenous forest and paddy field surrounding tribal village between the month of June-July 2019 and June-July 2020
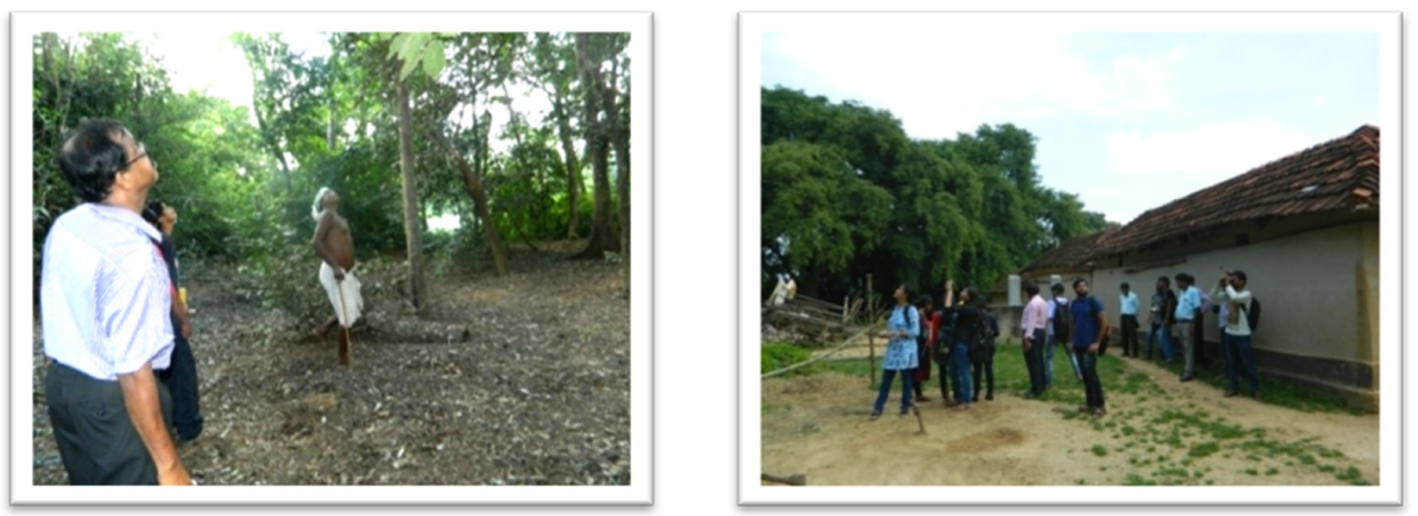

Figure 3. Data collection from tribal people of Barachaka Village, Bankura, West Bengal, India

Table 2. Checklist of avifaunal diversity from study area under present investigation

\begin{tabular}{|c|c|c|c|c|}
\hline $\begin{array}{r}\text { Sl } \\
\text { No. }\end{array}$ & Family & Common Name & Scientific name & IUCN Status \\
\hline 1 & \multirow{2}{*}{ Sturnidae } & Brahminy Starling & Sturnia pagodarum & LC \\
\hline 2 & & Common Myna & Acridotheres tristis & LC \\
\hline 3 & Dicruridae & Black Drongo & Dicrurus macrocercus & LC \\
\hline 4 & \multirow{6}{*}{ Ardeidae } & Great Egret & Casmerodius albus & $\mathrm{LC}$ \\
\hline 5 & & Median Egret & Ardea intermedia & LC \\
\hline 6 & & Cattle Egret & Bubulcus ibis & LC \\
\hline 7 & & Indian pond Heron & Ardeola grayii & LC \\
\hline 8 & & Chestnut Bittern & Ixobrychus cinnamomeus & LC \\
\hline 9 & & Black Crowned night Heron & Nycticorax nycticorax & LC \\
\hline 10 & Phalacrocoracidae & Little Cormorant & Microcarbo niger & LC \\
\hline 11 & \multirow{3}{*}{ Cuculidae } & Asian Koel & Eudynamys scolopaceus & LC \\
\hline 12 & & Pied Crested Cuckoo & Clamator jacobinus & LC \\
\hline 13 & & Crow Pheasant & Centropus sinensis & $\mathrm{LC}$ \\
\hline
\end{tabular}


Dey K et al. (2021). Not Sci Biol 13(2):10963

\begin{tabular}{|c|c|c|c|c|}
\hline 14 & NT+... & Loten;s sunbird & Cinnyris lotenius & LC \\
\hline 15 & Nectarminaae & Purple Sunbird & Cinnyris asiaticus & LC \\
\hline 16 & \multirow{5}{*}{ Columbidae } & Red Collared Dove & Streptopelia tranquebarica & LC \\
\hline 17 & & Green Pigeon & Treron bicinctus & LC \\
\hline 18 & & Common Pigeon & Columba livia & $\mathrm{LC}$ \\
\hline 19 & & Eurasian collared Dove & Streptopeliadecaocto & $\mathrm{LC}$ \\
\hline 20 & & Spotted Dove & Spilopelia chinensis & LC \\
\hline 21 & Oriolidae & Black-headed Oriole & Oriolus xanthornus & $\mathrm{LC}$ \\
\hline 22 & Monarchidae & Asian Paradise- flycatcher & Terpsiphone paradisi & LC \\
\hline 23 & Meropidae & Small Bee-eater & Merops orientalis & $\mathrm{LC}$ \\
\hline 24 & \multirow{2}{*}{ Psittaculidae } & Rose Ringed Parakeet & Psittacula krameri & LC \\
\hline 25 & & Alexandrine Parakeet & Psittacula eupatria & NT \\
\hline 26 & \multirow{3}{*}{ Corvidae } & House Crow & Corvus splendens & LC \\
\hline 27 & & Jungle Crow & Corvus macrorhynchos & LC \\
\hline 28 & & Rufoustreepie & Dendrocitta vagabunda & $\mathrm{LC}$ \\
\hline 29 & Passeridae & House Sparrow & Passer domesticus & $\mathrm{LC}$ \\
\hline 30 & \multirow{3}{*}{ Muscicapidae } & Oriental Magpie-robin & Copsychus saularis & $\mathrm{LC}$ \\
\hline 31 & & Indian Robin & Copsychus fulicatus & LC \\
\hline 32 & & Asian Brown Flycatcher & Muscicapa dauurica & $\mathrm{LC}$ \\
\hline 33 & \multirow{2}{*}{ Estrildidae } & Spotted Munia & Lonchura punctutata & LC \\
\hline 34 & & Black-Headed Munia & Lonchura malacca & $\mathrm{LC}$ \\
\hline 35 & Pycnonotidae & Red-Vented Bulbul & Pycnonotus cafer & $\mathrm{LC}$ \\
\hline 36 & Motacillidae & Paddy field Pipit & Anthus rufulus & LC \\
\hline 37 & \multirow{2}{*}{ Leiothrichidae } & Common Babbler & Turdoides caudatus & $\mathrm{LC}$ \\
\hline 38 & & Jungle Babbler & Argya striata & $\mathrm{LC}$ \\
\hline 39 & Upupidae & Common Hoope & Upupa epops & $\mathrm{LC}$ \\
\hline 40 & Ciconiidae & Asian Open bill Stork & Anastomus oscitans & LC \\
\hline 41 & Alcedinidae & Common Kingfisher & Alcedo atthis & LC \\
\hline 42 & Rallidae & White breasted water hen & Amaurornis phoenicurus & LC \\
\hline 43 & Charadridae & Yellow wattled lapwing & Vanellus malabaricus & LC \\
\hline 44 & Scolopacidae & Common Sandpiper & Actitis hypoleucos & LC \\
\hline 45 & Strigifae & Spotted Owlet & Athene brama & LC \\
\hline 46 & Cisticolidae & Common Tailorbird & Orthotomus sutorius & $\mathrm{LC}$ \\
\hline 47 & Picidae & lesser golden-backed woodpecker & Dinopium benghalense & LC \\
\hline
\end{tabular}

\section{Community participation of Asian open bill stork's conservation in Barachaka village}

Globally, 19 species of stork exist of which 9 species are found in India (Ali and Ripley,1987). The most common species in India is the Asian open bill stork (Anastomus oscitans). It is a resident breeder of Southeast Asia and resides in the tribal village of Barachaka, Bankura District, for almost six months of the year for breeding. But it has been observed that due to the expansion of human habitation near the heronry, there is a stiff decline in the global population in the past few decades (Bjorklund,1975; Tremblay and Ellison,1979; Carney and Sydeman, 1999).

It has been observed in our study that these birds mainly make their nests in the junction of two or three main branches of a tree. Various nesting stages of the Asian open bill stork have been observed including Preegg laying, egg-laying and chicks rearing (Figure 4). They mainly select big woody trees like Ankura (Alangium salviifolium), Papri (Holoptelea integrifolia) and Tamarind (Tamarindus indica) in this region. Also, these heronries are very close to the water sources.

For generations, the ethnic people residing in the tribal village of Barachaka of Bankura, have been actively engaged in the protection of the open bill stork and other resident birds. Since the arrival of these birds is related to the onset of the monsoon season (Dhua et al., 2013). Their arrival indicates the actual time to begin agricultural activities. Villagers do not cut the nesting tree for wood or fuel, nor are visitors and birdwatchers allowed near these trees (Figure 3). Sometimes they even forgot the tamarind harvest yield for sake of these 
birds, thus incurring a financial loss. Due to heavy rains, chicks may sometimes fall from their nests and are rescued by the villagers and returned to their original nests. Small children are also forbidden from setting off firecrackers near the trees during the nesting season. Similar heronry protection has been observed in some villages of Uttar Pradesh, Andhra Pradesh and Tamil Nadu (Pathak, 2009). Such an approach helps to increase the population by decreasing the mortality rate.
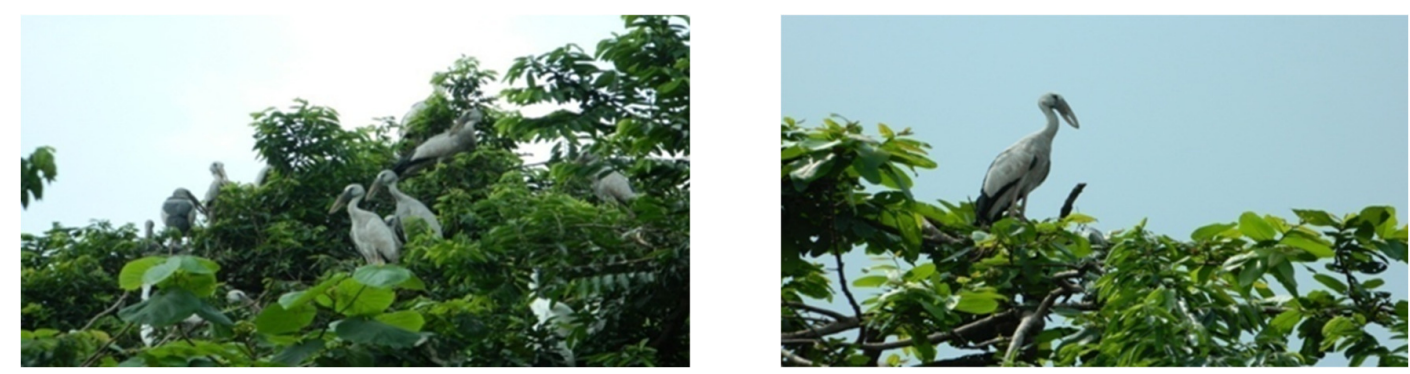

Figure 4. Asian open bill stork's colonial nest

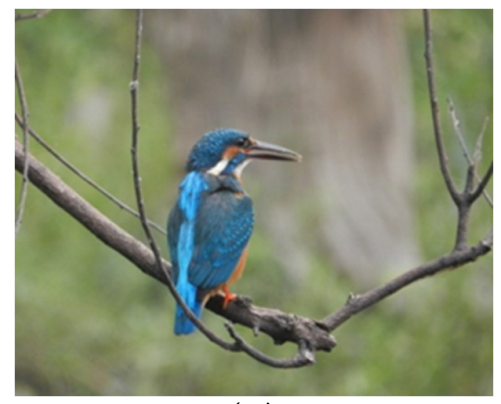

(A)

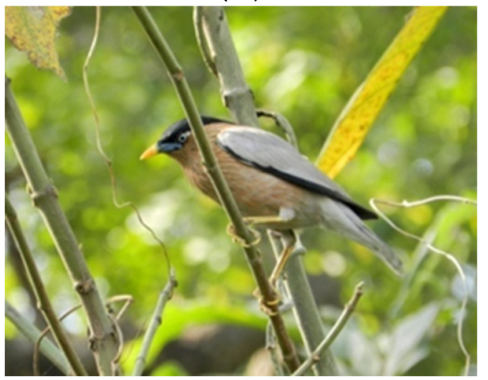

(D)

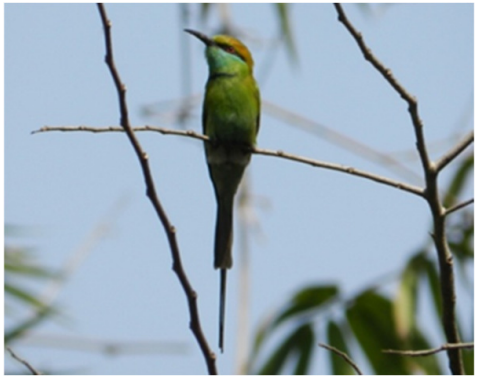

(G)

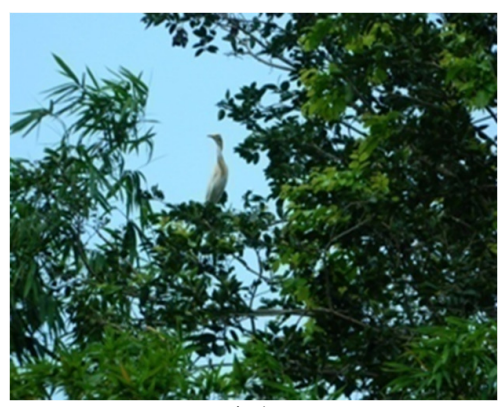

(B)

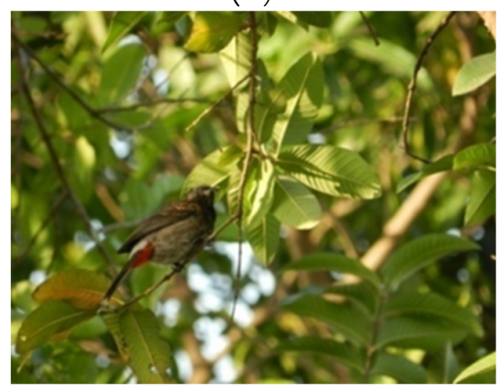

(E)

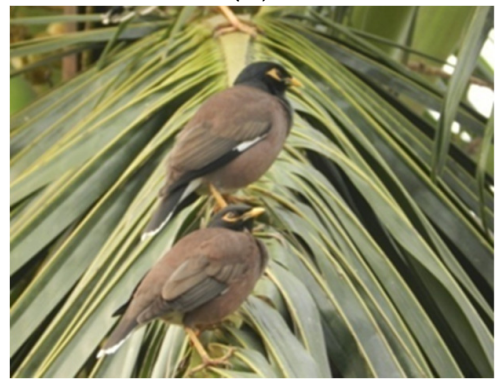

$(\mathrm{H})$

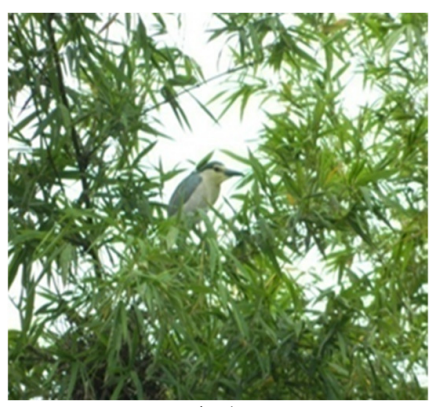

(C)

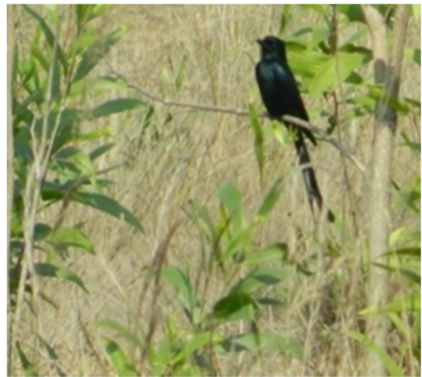

(F)

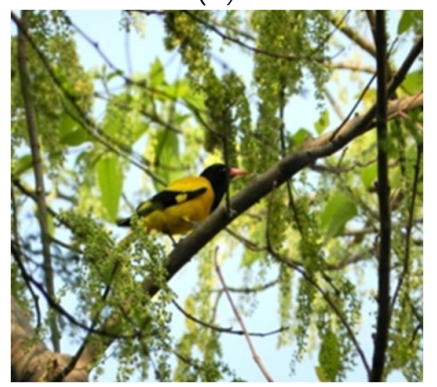

(I)

Figure 5. Bird diversity in the study area (A) Alcedo atthis (B) Bubulcus ibis (C) Nycticorax nycticorax

(D) Sturnia pagodarum (E)Pycnonotus cafer (F) Dicrurus macrocec (G)Merops oviertails

(H) Acridotheres tristis (I) Oriolus xanthornus 


\section{Discussion}

Birds can act as a perfect bio indicator and helpful model for accessing various environmental problems. Climatic condition, vegetation, availability of food, rail fall, presence of prey species and other ecological factors determine the bird population in any area (Dhua et al., 2013). Evaluation of local habitat and bird diversity of that particular area is necessary for proper avifaunal conservation (Kattan and Franco, 2004). In India approximately 1300 bird species have been recorded in the Indian subcontinent because of its diverse landscape like plain land, hills, Grassland, aquatic habitat, wetlands and marine environment with unique vegetation as well as varied climatic conditions which attract and give shelter to many bird species around the year (Grimmett et al., 1999). The result showed that in 2020 ( 47 species) was recorded from this study site which is greater than previously recorded studies (Dhua et al., 2013). As per IUCN's risk status, Alexandrine Parakeet (Psittacula eupatria) under the family Psittaculidae as near threatened (NT) but the status of other bird is the least concern.

In this study area, a maximum number of birds from one species counted were Asian open bill stork (545) in village forest. They select this village as a breeding ground during the rainy season, prepare colonial nest and lay eggs. As the village is surrounded by paddy field and aquatic bodies so they get plenty of food easily. Tribal people also protect them from wild animals as well as disturbance from bird watchers.

In the forest area, the Shannon-Weiner diversity index value of avifauna calculated to be 2.49 in the month of June-July, 2019 and 2.62 in the month of June-July, 2020 with a species richness value of 47 but in the paddy field species richness value are 38. But in both the habitat species evenness is more or less 0.67 to 0.69 in each year. The abundance of birds in the village is higher than paddy field because birds get food from domestic waste from tribal people. As well as they don't disturb them so a natural harmony was made between bird species and tribal people. The diversity of plant species also plays an important role in an abundance of birds in the study area. This statement also supported by the previous study of Wong (1986) and Barlow et al. (2007).

The abundance of species especially the breeding ground of Asian open bill stork in Barachaka tribal village creates potential attraction to bird lovers. Ecotourism provides earning source for active participating local communities as well as conservation of local flora; fauna of that particular was achieved. The potential of ecotourism of any area must be assessed before the development of ecotourism to understand local and community resources (Tseng et al., 2019). For the establishment of a new ecotourism site, its location, abundance of natural resources, accessibility, infrastructure, services should be examined (Yan et al., 2017). Now a day's local communities of many parts of the world came forward and their proactive and energetic participation helps to established successful tourism spot in their respective destination (Harun and Chiciudean, 2018). The development of ecotourism provides a solution for the local community related to the social and economic background and as well as for the conservation of biodiversity in the region. (Snyman, 2016)

Besides rural beauties, the avifaunal diversity of this region has the potential to develop a good bird watching site which may develop socio-economic status of the ethnic people of this region. The main profession of villagers of the study area is agriculture. As the area is dry and arid region so agricultural practice depends only on rainwater. So, in another season, these people choose an alternative profession like unskilled labour, rickshaw puller or other physical works. If ecotourism develops in the study site then the villagers may get the opportunity to share their knowledge with tourist as a guide as well as provide hospitality and lodging by using their home as homestay for nature lovers then they may earn some extra money in other seasons of the year. Mekonnen and Aticho (2011) also reported that bird watching activity in a particular area must be promoted because it creates a source of income for local communities and promoting environmental conservation. The scientific community may also gather lots of traditional knowledge from these people who may be helpful for bird conservation as well as for mankind. 


\section{Conclusions}

Most conventional conservation programs tend to be kept distance from human habitations. However, there are some exceptions like some conservation strategies which can be very effective near human habitations also. This requires integration of benefits of a natural system as well as the advantages of traditional knowledge of tribes handed over through generations. This will promote the co-utilization of a safe environment by motivating the ethnic people. High avifaunal diversity of this region demonstrates potential attraction for development of ecotourism spot.

Government and NGOs can play an important role through developing environmental awareness programme that makes villagers aware of the importance of biodiversity conservation through a suitable training programme. The conservation strategies would be much effective if we motivate the ethnic people who live in close harmony with the wild. The development of ecotourism increases environmental awareness as well as improves the financial status and welfare of local communities. The development of ecotourism activity in this area like bird watching site would be an added source of income for the villagers. This in turn would motivate them to actively conserve the local biodiversity thereby easing out the successful conservation of our biodiversity.

\section{Authors' Contributions}

RPM conceptualized and gathered data with regard to this work, documented and photographed the bird diversity, TKD collected the secondary data from tribal people and KD analysed the data and necessary inputs added towards the designing of the manuscript.

All authors read and approved the final manuscript.

\section{Ethical approval}

No birds were captured or killed or subjected to any experimental treatment during the study period.

\section{Acknowledgements}

This research received no specific grant from any government or non-government agencies. The authors want to acknowledge Principal, Bankura Sammilani College, Bankura and Principal, Midnapore College (Autonomous), Midnapore for their kind help and support in conducting the research work. The authors also want to acknowledge the help received from the people of Barachaka tribal village belonging to Bankura district of West Bengal, India.

\section{Conflict of Interests}

The authors declare that there are no conflicts of interest related to this article. 


\section{References}

Ali S, Ripley SD (1987). Compact handbook of the birds of India and Pakistan together with those of Bangladesh, Nepal, Bhutan and Sri Lanka. Delhi, Oxford University Press.

Barlow J, Overal WL, Araujo JS, Gardner TA, Press CA (2007). The value of primary, secondary and plantation forests for Amazonian birds. Journal of Applied Ecology 44(5):1001-1012. https://doi.org/10.1111/j.13652664.2007.01347.x

Birdlife International (1996). Important bird area in Africa, IBA criteria, categories and thresholds. Birdlife International, Cambridge.

Bjorklund RG (1975). On the death of mid western heronry. Wilson Bulletin 52:124-125.

Carney KM, Sydeman WJ (1999). A review of human disturbance effects on nesting colonial water birds, Waterbirds. 22(1):68-79. https://doi.org/10.2307/1521995

Clarke KR, Warwick RM (2001). Changes in marine communities: an approach to statistical analysis and interpretation. $2^{\text {nd }}$ edition, Primere, Plymouth.

Dhua B, Mondal RP, Dutta T (2013). Study of Anastomus oscitans (Boddaert) population in relation to rainfall and nest formation in Barachaka Village of Bankura District, West Bengal, India. International Journal of Advanced Research 1(9):358-363.

Gadgil M, Vartak VD (1976). Sacred groves of Western Ghats of India. Economic Botany 30:152-160.

Grimmet R, Inskipp C, Inskipp T (1999). Pocket guide to the birds of Indian Subcontinent. Oxford University Press, New Delhi.

Harisha MN, Hosetti BB (2009). Diversity and distribution of avifauna of Lakkavalli range forest, Bhadra wildlife sanctuary, Western Ghat, India. Ecoprint 16:21-27. https://doi.org/10.3126/eco.v16i0.3469

Harun R, Chiciudean GO, Sirwan K, Arion FH, Muresan IC (2018). Attitudes and Perceptions of the Local Community towards Sustainable Tourism Development in Kurdistan Regional Government, Iraq. Sustainability 10:2991. https://doi.org/10.3390/su10092991

Hussain KJ, Ramesh T, Satpathy K, Selvanayagam M (2011). A checklist of birds of Department of Atomic Energy Campus, Kalpakkam, Tamil Nadu. ZOO's Print 25 (7):13-20.

Hutchison K (1970). A test for comparing diversity based on the Shannon formula. Journal of Theoretical Biology 29(1):151-154. https://doi.org/10.1016/0022-5193(70)90124-4

Jones D (2010). Practices, needs and attitudes of bird-watching tourists in Australia. CRC for Sustainable Tourism. Australia, Gold Coast, Queensland.

Kattan GH, Franco P (2004). Bird diversity along elevational gradients in the Andes of Colombia: area and mass effects. Global Ecology and Biogeography 13:451-458.

Khan ML, Khumbongmayum AD, Tripathi RS (2008). The sacred groves and their significance in conserving biodiversity an overview. International Journal of Ecology and Environmental Sciences 34:277- 291.

Kharkongor BM, Tiwari BK (2017). Sacred groves of Meghalaya: a review. International Journal of Science and Research 6(3):346-349.

Lee PF, Ding TS, Hsu FH, Geng S (2004). Breeding bird species richness in Taiwan: distribution on gradients of elevation, primary productivity and urbanization. Journal of Biogeography 31:307-314. https://doi.org/10.1046/j.03050270.2003 .00988

Mekonnen T, Aticho A (2011). The driving forces of Boye Wetland degradation and its bird species composition, Jimma, Southwestern Ethiopia. Journal of Ecology and the Natural Environment 3(11):365-369.

Mondal RP, Dutta TK (2019). Anthropogenic impact on habitat of Lesser Whistling duck in Bankura Unnayani Institute of Engineering College, Bankura, W.B. Indian Science Cruiser 33(4):27-31.

Mondal RP, Dutta TK, Dhua B (2014). Reporting a new site record of the breeding population of Lesser adjutant (Leptoprilos javanicus) from Bankura district, West Bengal, India. International Journal of Current Research 6(1):4441-4443.

Narayanan PS, Vijayan L (2007). Status of the colonial breeding water birds in Kumarakom Heronry in Kerala, Southern India. Podoces 2(1):22-29.

Nayak A (2021). Nesting tree selection by scattered heronry birds of drought prone Nothern Bankura, West Bengal, India: preference of Phoenix sylvestris near wetland -associated habitats. Notulae Scientia Biologicae 13(1):1-16. https://doi.org/10.15835/nsb13110871

Pathak N (2009). Community conserved areas in India - A Directory. Klpavriksh, Pune/Delhi. 
Praveen J, Joseph JK (2006). A checklist of birds of the National Institute Technology Campus, Kozhikode, Kerala. Zoos' Print Journal 21(6):2298-2300. https://doi.org/10.11609/JoTT.ZPJ.1483.2298-300

Rist S, Burgoa FD, Wiesmann U (2003). The role of social learning processes in the emergence and development of Arymara land use systems. Mountain Research and Development 23(3):263-270.

Shannon CE, W Weaver (1949). The mathematical theory of communication. University of Illinois Press, Urbana, Illinois.

Sitanggang FI, Budiman MAK, Afandy A (2020). Bird diversity: the potential of avi-tourism reserves for bird conservation in Curup Tenang, South Sumatera, Indonesia. Jurnal Biodjati 5(2):249-258. https://doi.org/10.15575/biodjati.v5i2.9537

Snyman S (2016) The role of private sector eco-tourism in local socio-economic development in Southern Africa. Journal of Ecotourism 247-268. https://doi.org/10.1080/14724049.2016.1226318

Sodhi NS (2011). Conservation of tropical birds. Blackwell Publishing. USA.

Steven R, Morrison C, Castley JG (2014). Birdwatching and avitourism: a global review of research into its participant markets, distribution and impacts, highlighting future research priorities to inform sustainable avitourism $\begin{array}{lllll}\text { management. Journal of } & \text { Tourism }\end{array}$ https://doi.org/10.1080/09669582.2014.924955

Tremblay J, Ellison LN (1979). Effects of human disturbance on breeding of Black-crowned Night Herons. The Auk 96:364-369.

Tseng ML, Lin C, Remen Lin CW, Wu KJ, Sriphon T (2019). Ecotourism development in Thailand: community participation leads to the value of attractions using linguistic preferences. Journal of Cleaner Production 231:1319-1329. https://doi.org/10.1016/j.jclepro.2019.05.305

Urfi AJ (2005). Counting birds in India: methodologies and trends. Current Science 89(12):1997-2003. https://www.jstor.org/stable/24111060

Wong M (1986). Tropic organization of understory birds in a Malaysian Dipterocarp forest. Auk 103:100-116. https://doi.org/10.1093/AUK/103.1.100

Yan L, Gao W, Zhang M (2017). A mathematical model for tourism potential assessment. Tourism Management 63:355365. https://doi.org10.1016/j.tourman.2017.07.003

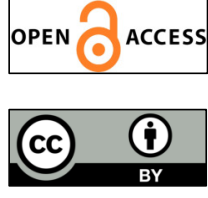

The journal offers free, immediate, and unrestricted access to peer-reviewed research and scholarly work. Users are allowed to read, download, copy, distribute, print, search, or link to the full texts of the articles, or use them for any other lawful purpose, without asking prior permission from the publisher or the author.

License - Articles published in Notulae Scientia Biologicae are Open-Access, distributed under the terms and conditions of the Creative Commons Attribution (CC BY 4.0) License.

(c) Articles by the authors; SHST, Cluj-Napoca, Romania. The journal allows the author(s) to hold the copyright/to retain publishing rights without restriction. 